\title{
ANALISIS ECONOMIC VALUE ADDED (EVA) SEBAGAI ALAT UKUR KINERJA KEUANGAN BANK SYARIAH
}

\author{
Yuricke Marshella $^{1)}$, Karuniawati Hasanah ${ }^{2)}$ \\ ${ }^{1}$ Fakultas Ekonomi dan Bisnis, UNIVERSITAS PGRI MADIUN \\ email: yurickemarshella@gmail.com \\ ${ }^{2}$ Fakultas Ekonomi dan Bisnis, UNIVERSITAS PGRI MADIUN \\ email: karuniawatihasanah@gmail.com
}

\begin{abstract}
This study uses descriptive studies with the aim to provide an overview of the aspects that are relevant in this case to help managers make decisions for the company. The subject of this research is a Sharia Commercial Bank registered with the Financial Services Authority. The instruments in this study are quarterly financial reports from Sharia Commercial Bank. The analysis technique used in this research is descriptive analysis.The results showed that Bank Muamalat pioneered the sharia banks in creating EVA but in 2016 and 2017 experienced a decline in economic value to not add value. This can happen because the muamalat decreases earnings to increase the amount of debt in the company. While the BJB bank does not create much added value even EVA is obtained is always negative this can be influenced by the amount of profit less than the amount of debt high enough, this can trigger kurannya interest shareholeder to invest in the bank.
\end{abstract}

Keywords: Sharia Commercial Bank, Economic Value Added

\begin{abstract}
Abstrak
Penelitian ini menggunakan studi deskriptif dengan tujuan untuk memberikan gambaran aspekaspek yang relevan dalam kasus ini untuk membantu manajer mengambil keputusan untuk perusahaan. Subyek penelitian ini adalah Bnk Umum Syariah yang terdaftar pada Otoritas Jasa Keuangan (OJK). Instrumen pada penelitian ini instrumen yang digunakan adalah laporan keuangan triwulan dari Bank Umum Syariah. Teknik analisis yang digunakan dalam penelitian ini adalah dengan analisis deskriptif. Hasil penelitian menunjukkan bahwa Bank Muamalat menjadi pionir para bank syariah dalam menciptakan EVA tetapi pada tahun 2016 dan 2017 mengalami penurunan nilai ekonomi hingga tidah dapat memberi nilai tambah. Ini dapat terjadi dikarenakan muamalat mengalami penurunan laba hingga peningkatan jumlah hutang yang ada di perusahaan. Sedangkan pada bank BJB tidak banyak menciptakan nilai tambah bahkan EVA yang diperoleh selalu negatif ini dapat dipengaruhi oleh jumlah laba yang kurang dari jumlah hutang yang cukup tinggi, hal ini dapat memicu kurannya minat shareholeder untuk menanamkan modalnya pada bank tersebut.
\end{abstract}

Kata Kunci: Bank Syariah, Nilai Tambah Ekonomi

\section{A.PENDAHULUAN}

Perbankan di Indonesia telah mengalami perubahan dari waktu ke waktu, perubahan ini disebabkan oleh perkembangan internal dan eksternal dunia perbankan, pengaruh luar dunia perbankan misalnya seperti sektor riil dalam perekonomian, politik, hukum, dan sosial. Di Indonesia, perbankan memiliki peranan untuk mendorong pertumbuhan ekonomi dengan kegiatan investasi. Perbankan sebagai lembaga intermediary memiliki fungsi mengumpulkan tabungan masyarakat 
dan menyalurkannya kembali salah satunya berupa kredit investasi sejak dilaksanakannya deregulasi pertama di Indonesia di tahun 1983 tepatnya pada tanggal 1 Juni 1983, setiap bank memiliki keleluasaan untuk menentukan suku bunga sehingga industri perbankan semakin kompetitif. (Bank Indonesia, 2013).

Di dalam dunia perbankan terdapat 2 jenis bank antara lain Bank Konvensional dan Bank Syariah. Menurut Undang-Undang No 10 tahun 1998 Bank konvensional merupakan bank yang melaksanakan kegiatan usaha secara konvensional yang dalam kegiatannya memberikan jasa dalam lalu lintas pembayaran, sedangkan Bank syariah adalah bank yang melaksanakan kegiatan usahanya berdasarkan prinsip syariah yang dalam kegiatannya memberikan jasa dalam lalu lintas pembayaran.

Perkembangan sistem pada perbankan syariah di Indonesia dilakukan dengan dual-banking system dalam kerangka Arsitektur Perbankan Indonesia (API), dengan maksud menghadiran perbankan yang semakin lengkap untuk masyarakat Indonesia. Dengan berlakunya Undang - undang No.20 Tahun 2008 tentang Perbankan
Syariah pada tanggal 16 Juli 2008, membuat Perbankan Syariah memiliki landasan hukum yang memadai dan secara cepat mendorong pertumbuhannya. Perbankan Syariah juga diharapkan untuk mendukung pertumbuhan ekonomi nasional secara signifikan. (Bank Indonesia, 2013).

Economic Value Added (EVA) pertama kali dicetuskan oleh Stewart \& Company memiliki definisi sebagai laba operasi setelah pajak dikurangi biaya modal (cost of capital) dari total modal yang digunakan untuk menghasilkan laba.(Stewart, 1991). Konsep EVA dalam penggunaannya mengakibatkan perusahaan untuk menitikberatkan pada struktur modal. Pada dasarnya perhitungan EVA itu pada economic profit yang mana pengukurannya pada periode waktu tertentu, disini peningkatan saham perusahaan dapat tercipta apabila kinerja menejemen efektif dari nilai tambah yang dihasilkan. Hal ini dapat membantu manajer untuk memaksimalkan nilai pemegang saham karena konsep EVA dapat membuat manajer mengerti pola pikir investor, yaitu memilih investasi yang memiliki tingkat pengembalian tinggi sedangkan tingkat modal yang 
rendah sehingga nilai perusahaan bisa maksimal.(Brigham, 1996).

\section{B. METODE PENELITIAN}

Penelitian ini menggunakan studi deskriptif dengan tujuan untuk memberikan gambaran aspek - aspek yang relevan dalam kasus ini untuk membantu manajer mengambil keputusan untuk perusahaan kedepannya juga untuk menjelaskan EVA dapat menjadi alat ukur kinerja keuangan pada Bank Syariah. Studi waktu yang di gunakan adalah studi cross-sectional yang mana menurut Uma Sekaran (2013) merupakan studi dengn data yang dikumpulkan hanya sekali seperti periode harian, mingguan, atau bulanan untuk menjawap pertanyaan dari penelitian. Dengen menggunakan studi cross-sectional peneliti mengambil periode triwulan pada lima tahun laporan keuangan bank syariah dari tahun 2013 hingga 2017 ini dimaksudkan untuk mempermudah peneliti untuk menggambarkan kondisi kinerja keuangan menggunakan analisis Economic Value Added di setiap tiga bulan sekali pertahunnya.

Metode pengumpulan dengan dokumen digunakan untuk memperoleh data sekunder yang telah didokumentasikan dan relevan dengan masalah dalam penelitian.

Jenis data yang digunakan merupakan data kuantitatif, yaitu laporan keuangan tahunan Bank Umum Syariah yang tercatat pada OJK. Sumber data penelitian yang merupakan data sekunder didapatkan dari laporan keuangan yang telah diaudit. Data tersebut diperoleh dari website resmi Bank Syariah yang menjadi Obyek penelitian.

Dengan data yang telah dikumpulkan peneliti menggunakan analisi kinerja keuangan menggunakan metode Economic Value Added (EVA) dengan rumus sebagai berikut :

EVA $=$ NOPAT - Biaya modal setelah pajak

NOPAT merupakan Laba bersih setelah pajak yang memiliki perhitungan rumus NOPAT $=$ EBIT $x$ (1 - tarif pajak), dan biaya modal setelah pajak dihitung dengan perkalian dari operating capital dan biaya modal perusahaan setelah pajak. Maka rumus dasarnya menjadi, 
$\mathrm{EVA}=\mathrm{EBIT} \quad(1-$ tarif pajak $)-$ (Operating capital)(biaya modal perusahaan setelah pajak)

Total biaya modal menunjukan besarnya kompensasi atau pengembalian yang diminta investor atas modal yang diinvestasikan di perusahaan. Besarnya kompensasi tergantung pada tingkat risiko perusahaan yang bersangkutan, dengan asumsi bahwa investor bersifat penghindar resiko, semakin tinggi tingkat resiko semakin tinggi tingkat pengembalian yang diminta investor.

Modal terdiri dari modal sendiri (ekuitas) berasal dari para pemegang saham, dan utang dari para kreditor atau pemegang obligasi perusahaan. Besarnya tingkat biaya modal ditentukan brdasarkan rata-rata tertimbang (weighted average cost of capital) dari biaya modal sendiri (cost of equity) dan biaya utang setelah pajak sesuai dengan proporsi modal sendiri dan utang dalam struktur modal perusahaan.

Kriteria untuk menentukan nilai tambah perusahaan sebagai berikut:

- Jika EVA >0

Maka perusahaan dapat menciptakan nilai tambah, hal ini berarti kinerja keuangan perusahaan baik sehingga dapat memberikan nilai tambah bagi pemegang saham.

- Jika EVA = 0

Maka perusahaan terjadi titik impas, hal ini berarti laba perusahaan impas untuk membayar semua kewajiban pada kreditur dan investor.

- Jika EVA < 0

Maka perusahaan tidak dapat menciptakan nilai tambah, hal ini berarti kinerja keuangan perusahaan tidak baik sehingga perusahaan tidak mampu memberikan pengembalian yang setimpal pada kreditur dan investor.

\section{HASIL DAN PEMBAHASAN}

Pada grafik yang tersaji terlihat bahwa Bank Muamalat menjadi pionir para bank syariah dalam menciptakan EVA tetapi pada tahun 2016 dan 2017 mengalami penurunan nilai ekonomi hingga tidah dapat memberi nilai tambah. Ini dapat terjadi dikarenakan muamalat mengalami penurunan laba hingga peningkatan jumlah hutang yang ada di perusahaan. Sedangkan pada bank BJB tidak banyak menciptakan nilai tambah bahkan EVA yang diperoleh selalu negatif ini dapat dipengaruhi oleh jumlah laba yang 
kurang dari jumlah hutang yang cukup tinggi, hal ini dapat memicu kurangnya minat calon investor untuk berinvestasi pada bank tersebut.

Jadi seperti yang sudah dijelaskan bahwa EVA berupa penambahan nilai tambah ekonomi pada suatu perusahaan yang dinyatakan dalam rupiah pada jangka waktu tertentu dan bukan sebagai rasio persentase pengembalian. EVA digunakan sebangai tolak ukur kinerja keuangan dari mengukur perbedaan pengembalian atas modal perusahaan dengan biaya modal yang mana indikator dari penambahan nilai dari investasi dan nilai ekonomis yang diciptakan perusahaan dari kegiatan selama periode tertentu dan merupakan salah satu penilaian dari kinerja keuangan. Hasil yang didapat dari perhitungan nilai tambah ekonomi yang diberikan kepada pemegang saham sebagai akibat dari aktivitas perusahaan ini berarti pemegang saham mendapat nilai tambah dari pada nilai yang tercipta perusahaan terkait

Tabel 1. Tabel hasil perhitungan EVA dari setiap Bank

\begin{tabular}{|c|c|c|c|c|c|}
\hline EVA & BCA SYARIAH & BJB SYARIAH & $\begin{array}{c}\text { BNI } \\
\text { SYARIAH }\end{array}$ & $\begin{array}{c}\text { BRI } \\
\text { SYARIAH }\end{array}$ & $\begin{array}{l}\text { BUKOPIN } \\
\text { SYARIAH }\end{array}$ \\
\hline \multicolumn{6}{|l|}{2013} \\
\hline MAR & 241 & 648 & 6,341 & 9,162 & 1,409 \\
\hline JUN & 756 & 792 & 13,523 & 20,038 & 2,988 \\
\hline SEP & 1,258 & 1,256 & 25,841 & 26,829 & 4,256 \\
\hline DES' & 1,458 & 2,610 & 26,337 & 21,024 & 5,089 \\
\hline \multicolumn{6}{|l|}{2104} \\
\hline MAR & 458 & (36) & 6,395 & 3,337 & 1,039 \\
\hline JUN & 769 & 7 & 7,161 & $(1,046)$ & 2,104 \\
\hline SEP & 1,185 & 422 & 15,152 & 212 & 3,280 \\
\hline DES' & 1,400 & 1,468 & 23,308 & $(1,056)$ & 3,326 \\
\hline \multicolumn{6}{|l|}{2015} \\
\hline MAR & 392 & 29 & 7,287 & 2,639 & 1,151 \\
\hline JUN & 1,255 & 751 & 1,480 & 8,580 & 2,816 \\
\hline SEP & 1,675 & 498 & $(19,506)$ & 8,748 & 5,219 \\
\hline DES' & 2,187 & 1,654 & $(2,781)$ & 16,225 & 5,956 \\
\hline \multicolumn{6}{|l|}{2016} \\
\hline MAR & 680 & 305 & 10,266 & 11,702 & 1,752 \\
\hline JUN & 1,399 & $(2,074)$ & 21,994 & 23,778 & 3,919 \\
\hline SEP & 2,519 & $(9,568)$ & 33,593 & 28,606 & 5,657 \\
\hline
\end{tabular}


Yuricke $^{(1)}$, Karuniawati ${ }^{(2)}$, Analisis Economic Value Added

\begin{tabular}{|c|c|c|c|c|c|}
\hline DES' & 2,975 & $(290,004)$ & 33,860 & 33,001 & 6,914 \\
\hline \multicolumn{6}{|l|}{2017} \\
\hline MAR & 564 & 75 & 13,068 & 6,028 & 1,268 \\
\hline JUN & 1,495 & 390,057 & 29,793 & 15,187 & 1,645 \\
\hline SEP & 4,341 & 10,419 & 29,875 & 22,300 & 2,031 \\
\hline DES' & 6,028 & $(100,910)$ & 61,613 & 13,216 & 4,643 \\
\hline EVA & $\begin{array}{l}\text { MANDIRI } \\
\text { SYARIAH }\end{array}$ & $\begin{array}{l}\text { MAYBANK } \\
\text { SYARIAH }\end{array}$ & $\begin{array}{c}\text { MEGA } \\
\text { SYARIAH }\end{array}$ & MUAMALAT & $\begin{array}{c}\text { PANIN } \\
\text { SYARIAH }\end{array}$ \\
\hline \multicolumn{6}{|l|}{2013} \\
\hline MAR & 30,086 & 1,569 & 9,623 & 15,031 & 1,004 \\
\hline JUN & 46,431 & 1,125 & 18,252 & 38,583 & 3,764 \\
\hline SEP & 53,978 & 2,297 & 20,942 & 54,492 & 5,505 \\
\hline DES' & 93,541 & 3,938 & 7,808 & 95,987 & 1,912 \\
\hline \multicolumn{6}{|l|}{2104} \\
\hline MAR & 23,052 & 2,620 & 6,204 & 21,374 & $(2,567)$ \\
\hline JUN & 16,132 & 1,960 & 6,359 & 35,072 & $(1,329)$ \\
\hline SEP & 28,903 & 5,005 & 2,479 & 23,006 & 2,043 \\
\hline DES' & (771) & 2,385 & 1,718 & 35,893 & 10,990 \\
\hline \multicolumn{6}{|l|}{2015} \\
\hline MAR & 9,009 & (748) & $(4,019)$ & 13,738 & 2,140 \\
\hline JUN & 14,047 & $(19,619)$ & $(6,648)$ & 20,803 & 3,949 \\
\hline SEP & 14,888 & $(15,344)$ & $(8,852)$ & 30,306 & 6,753 \\
\hline DES' & 22,475 & $(38,301)$ & $(6,283)$ & 7,367 & $(42,096)$ \\
\hline \multicolumn{6}{|l|}{2016} \\
\hline MAR & 6,460 & $(1,346)$ & 3,027 & 7,367 & 393 \\
\hline JUN & 23,833 & $(13,415)$ & 1,269 & $(18,712)$ & 809 \\
\hline SEP & 27,428 & $(21,490)$ & 26,243 & 2,237 & 2,657 \\
\hline DES' & 36,884 & $(34,784)$ & $(2,821)$ & $(13,309)$ & 1,767 \\
\hline \multicolumn{6}{|l|}{2017} \\
\hline MAR & 13,100 & 1,585 & $(1,949)$ & 5,986 & 1,386 \\
\hline JUN & 30,063 & 12,794 & (46) & 17,063 & 1,275 \\
\hline SEP & 40,906 & 6,206 & $(1,194)$ & 14,508 & 967 \\
\hline DES' & 26,292 & $(2,109)$ & (11) & $(4,582)$ & $(50,275)$ \\
\hline
\end{tabular}




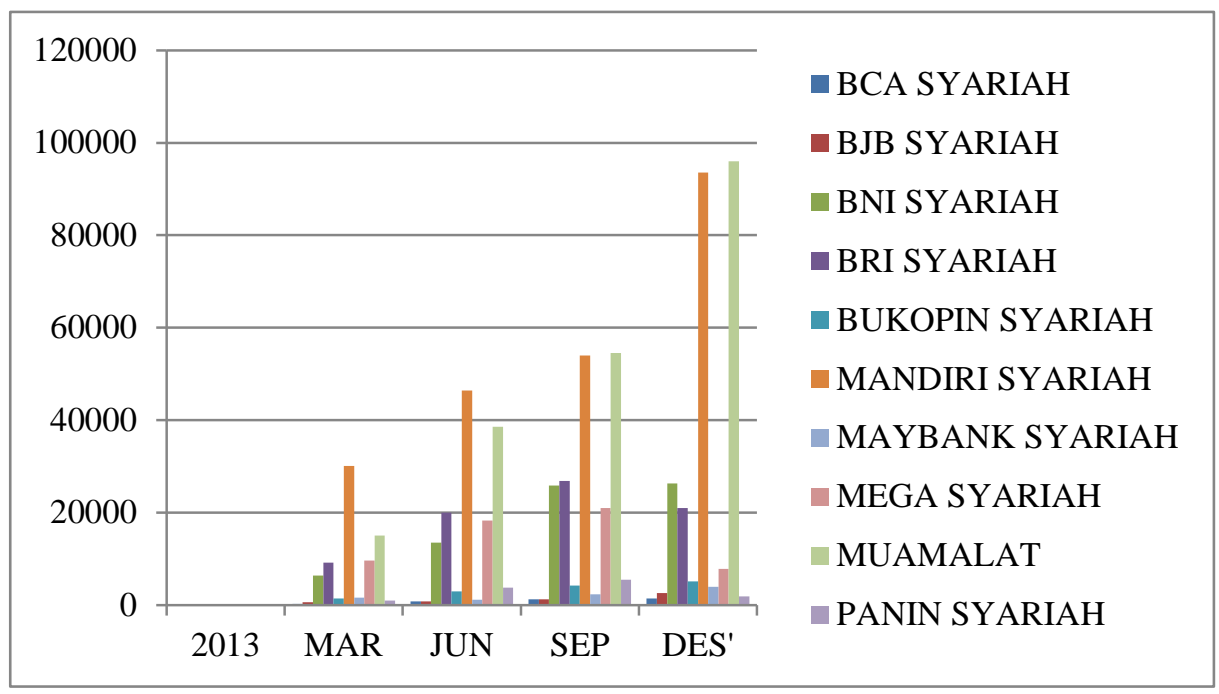

Gambar 1 Grafik hasil perhitungan EVA dari setiap Bank tahun 2013

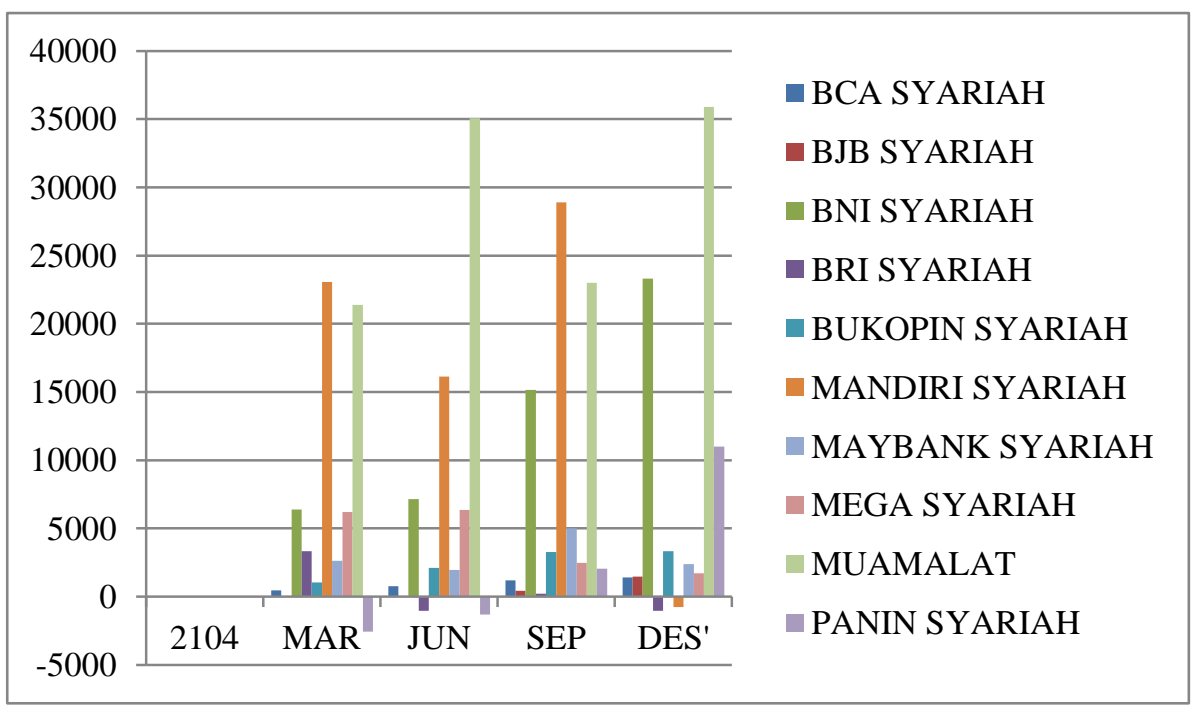

Gambar 2 Grafik hasil perhitungan EVA dari setiap Bank tahun 2014 


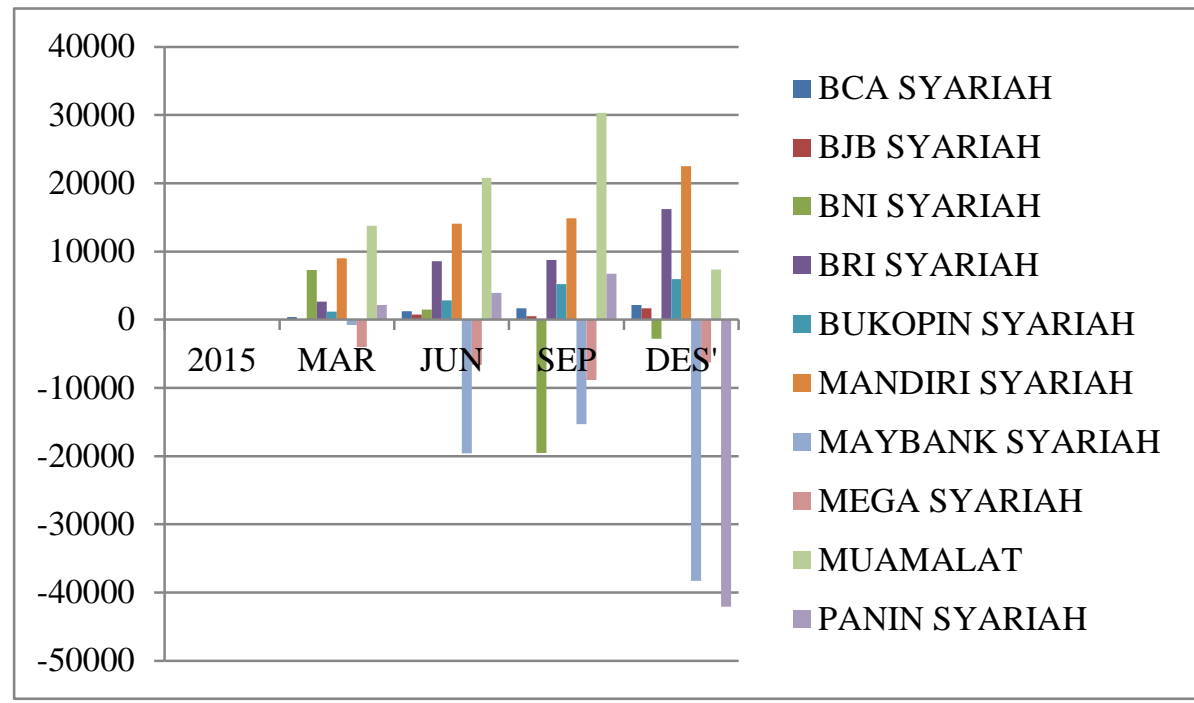

Gambar 3 Grafik hasil perhitungan EVA dari setiap Bank tahun 2015

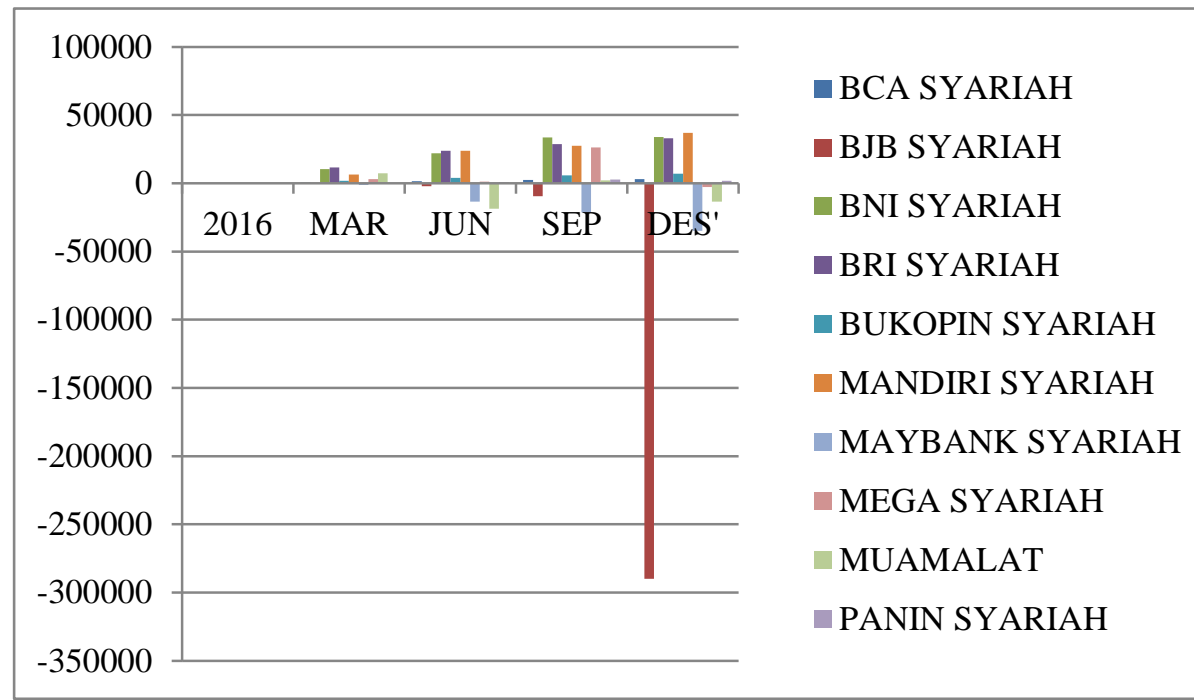

Gambar 4 Grafik hasil perhitungan EVA dari setiap Bank tahun 2016 


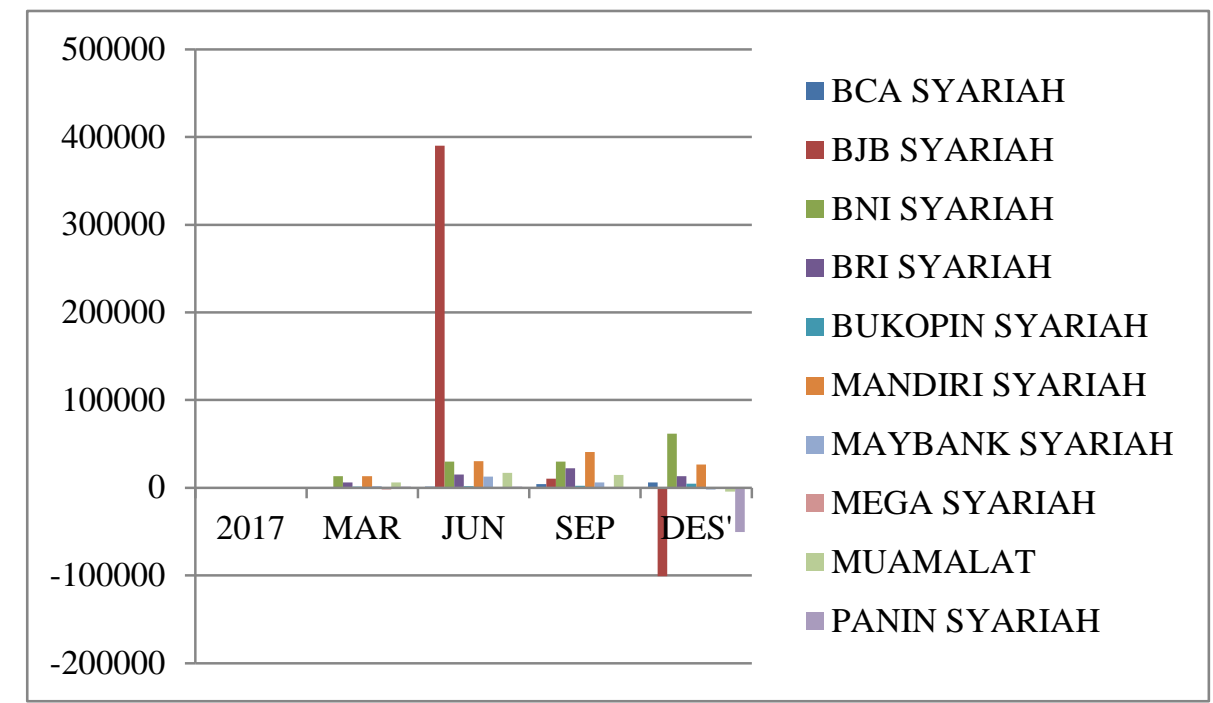

Gambar 5 Grafik hasil perhitungan EVA dari setiap Bank tahun 2017

\section{SIMPULAN}

Berdasarkan dari hasil analisis dari Economic Value Added Sebagai alat ukur bank Syariah pada tahun 2013 - 2017, maka Economic Value Added dapat mengukur kinerja keuangan perusahaan, ini ditandai dengan dapat dilihat kemampuan perusahaan dalam menciptakan nilai tambah, ini juga berpengaruh pada calon investor yang ingin menanamkan investasi pada perusahaan.
Perolehan nilai tambah setiap bank berbeda - beda dimulai dari BCA Syariah yang memiliki tingkat nilai tambah yang cukup stabil, lalu bank Muamalat yang merupakan pelopor bank syariah di Indonesia yang memiliki tingkat EVA yang tinggi dari bank lain tetapi mengalai penurunan pada tahun 2017. Pada dasarnya semua bank mampu menciptakan nilai ekonomi hanya saja nilai yang didapat terkadang positif terkadang negatif, ini mempengaruhi kemampuan perusahaan dalam membayar semua kewajibannya.

\section{DAFTAR RUJUKAN}

Aisiyah, Nurul. 2013. Pengukuran Kinerja Keuangan Perusahaan Menggunakan Metode rasio Keuangan dan Metode EVA. Jurnal Administrasi Bisnis . vol 2, no 1 
Brealy, Myers, Marcus. 2008. Dasara - dasar manajemen Keuangan Perusahaan. Edisi Kelima. Badan penerbit : Erlangga

Brigham, Houston. 2015. Dasar - Dasara Manajemen keuangan. Edisi 11 Buku 1. Badan Penerbit : Salemba Emapat

Husnan, Suad. 2015. Dasar - Dasar manajemen Keuangan. Edisi Ketujuh. Badan Penerbit :UPP STIM YKPNSugiyono. 2013. Metode Penelitian Kuantitatif, Kualitatif, dan kombinasi (Mix Methods). Badan Penerbit: Alvabeta Cv.

Ismani, Setiawan, Istiningrum. 2011. Analisis Profitabilitas untuk Mengukur Kinerja Keuangan manajemen Hotel. Jurnal Akuntansi Indonesia. Vol 9. No 2. Halaman 72-78

Jilly, Karamoy. 2016. Analisis Economic Value Added (EVA) pada PT. Bank Negara IndonesiaTbk. Jurnal Administrasi Bisnis

Keown, Martin, Petty, Scott. 2010. Manajemen keuangan. Edisi kesepuluh Jilid 2. Badan penerbit : Indeks

Mubarok, Dewi. 2010. Analisis Kinerja Keuangan Perusahaan dengan metode Economic Value Added. Jurnal Manajemen dan organisasi. Vol 1. No 2

Nugrahini, Kusumawati. 2017. Economic Value Added (EVA) Sebagai Alat Ukur Kinerja Keuangan Perusahaan. Jurnal Akademika. Volume 1. No. 1

Pradhono. 2004 . Pengaruh Economin Value Added, Residual Income, Earnings, Dan Arus Kas Operasi Terhadap Return Yang Diterima Oleh Pemegang Saham. Jurnal Akuntansi dan keuangan. Vol 6. No 2. Halaman 140-166

Riseth, Patel. 2002 Impact Of Economic Value Added (EVA) On Shared Price. International Jurnal Of Contemporary Business Studies. Vol 3. No 1.

Rudianto. 2013. Akuntansi Menejemen. Badan Penerbit : Erlangga

Sekaran, Uma. 2006, Research Methods for Business. Buku 2 Edisi 4. Badan penerbit : Salemba Empat

Sekaran, Uma. 2014, Research Methods for Business. Buku 1 Edisi 4. Badan penerbit : Salemba Empat

Supryanto. 2009. Metodologi Riset Bisnis. Badan Penerbit : Indeks

Triwahyuningtyas, Ismail. 2014. Analisis Kinerja Keuangan bank Umum Syariah Dan faktor faktor yang Mempengaruhinya. E-Jurnal Manajemen Keuangan

Yuli, Andriansyah. 2009. Kinerja Keuangan Perbankan Syariah di Indonesia dan Kontribusinya bagi pembangunan Nasional. Jurnal Ekonomi Islam. Vol 3. No 2

Yumanita, Diana. 2005. Gambaran umum: Bank Syariah. Seri Kebanksentrakan. No 14 
Yuricke $^{(1)}$, Karuniawati ${ }^{(2)}$, Analisis Economic Value Added

Zahara, Haryanti. 2011. Pengukuran Kinerja Keuangan dengan Menggunakan Metode Economic Value Added pada PT Telekomunikasi Indonesia. Proseeding PESAT. Vol 4 